\title{
SHARP POWER, YOUTH POWER, AND THE NEW POLITICS IN TAIWAN \\ Graeme Read
}

TN 2018, the People's Republic of China (PRC) stepped up efforts to isolate Taiwan and hinder its quest for international recognition. Three countries formerly maintaining full diplomatic relations with the Republic of China (ROC) - the Dominican Republic, Burkino Faso, and El Salvador - broke these ties to establish them with the PRC, reducing Taiwan's political allies to just seventeen worldwide. Not just a matter of chequebook diplomacy, this represents a spike in Beijing's application of 'sharp power' - a term coined in a National Endowment for Democracy report in 2017, and discussed in detail in chapter 2 of the report. ${ }^{1}$ Sharp power signifies influence that 'pierces, penetrates, or perforates the political and information environments in the targeted countries', particularly that deployed by authoritarian regimes to enforce their objectives abroad.

In the case of Taiwan, China's growing use of sharp power can be traced to the 2016 election of Tsai Ing-wen's 蔡英文 Democratic Progressive Party (DPP) government. The DPP won both executive and legislative power, crystallising popular dissatisfaction with the pro-China Kuomintang (KMT) government. At the same time, 'third force' minor parties rose to prominence, presenting alternatives to Taiwan's two-party politics. In 2018, these parties, fuelled by young activists' disillusionment with establishment politics, prepared for the November elections and the chance to embed the politics of 'youth power' into local political structures. 
The Sunflower Student Movement 太陽花學運 of 2014, during which students occupied the Legislative Yuan and forced the government to suspend the Cross-Strait Service Trade Agreement, was a critical moment for Taiwan's civil society. (see the China Story Yearbook 2014: Shared Destiny, Forum 'Occupy Taiwan', pp.136-145). Activists proved they could effectively mobilise and deploy 'people power' outside either of the two major parties. From this movement emerged what is now the third-largest parliamentary party: the New Power Party (NPP). The NPP - cofounded by heavy metal vocalist, former chair of Amnesty International Taiwan, and independence activist Freddy Lim 林永佐 - explicitly presented itself as the direct successor of the youth activist movement, heralding a new era of politics and youth power that sought to transform Taiwan's government into one more responsive to the people's needs and wishes.

Since the 2016 elections, the NPP has distanced itself from the DPP, with which it once cooperated against their common enemy, the KMT. Throughout 2018, the NPP broke with DPP platforms in both parliament and public. While the DPP was Taiwan's original opposition party, with roots in martial law-era activism, it has since become more moderate and no longer explicitly advocates Taiwanese independence. On paper, the NPP's reformist agenda and liberal-democratic values are similar to those of the DPP. But the NPP attracts both independence advocates and social activists disillusioned by the DPP. The NPP advocates progressive democracy fused with localisation: rendering Taiwan a 'normal' sovereign country, reconciling with injustices of an authoritarian past, and deepening transparent and participatory democracy.

In early January 2018, five NPP legislators staged a hunger strike to protest the DPP's proposed amendments to the Labour Standards Act to remove protective stipulations regarding workers' time off and rest periods. They accused the DPP of being beholden to business interests at the expense of its working base. The KMT stood with the NPP in criticising the governing DPP, disconcerting some of the NPP's hardcore anti-KMT supporters. The NPP also criticised the DPP for inaction on marriage equality, after the Constitutional Court ruled current marriage laws invalid in 2017. The NPP nevertheless supported the DPP government's proposed pension re- 


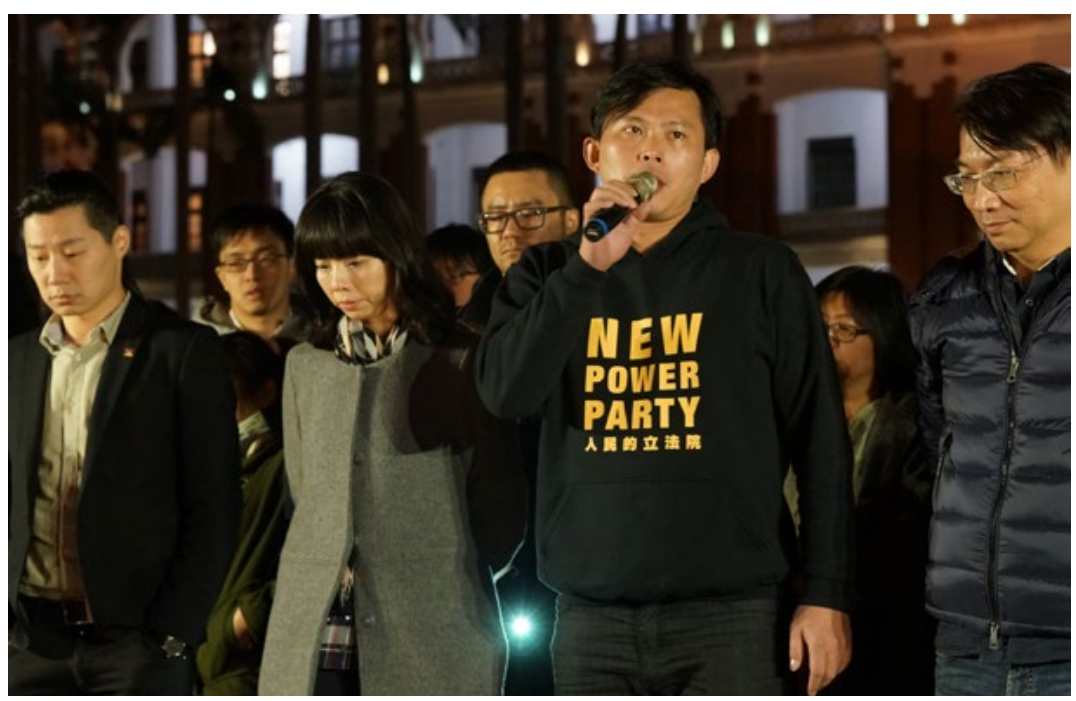

New Power Party hunger strike outside the Presidential Office Building, Taipei, January 2018. Freddy Lim can be seen in the far left of the picture

Source: 影中 王, Flickr

forms, to the ire of KMT-aligned vested interests. The Party thus demonstrated an issue-based approach to policy, rather than falling into an anti-KMT coalition with the DPP. Willing to challenge both major parties on issues of national identity and social welfare, the NPP positioned itself as being more idealistic than the pragmatic DPP.

The district elections in November coincided with several referendums following a revision of the Referendum Act that took effect in January. The new Act significantly reduced thresholds required to propose a national ballot and the minimum voter turnout for a valid referendum. The minimum voting age for referendums was also lowered to eighteen. A referendum was first proposed by Thomas Liao Wen-I 廖文毅 during the 1940s KMT era as a means of enacting Taiwanese self-determination, and further accompanied the rise of activism in the 1980s and democratisation in the 1990s. ${ }^{2}$ Rather than resolving the question of Taiwan's sovereignty, however, referendums largely became tools of KMT-DPP electioneering. The majority have failed to secure minimum voter turnouts, thanks to the parties putting up simultaneous, 
competing proposals, as well as calls for boycotts. ${ }^{3}$ Importantly, this year's referendums were not deployed by either major party but by activists as means of direct political participation. Approximately half of the proposed referendums aimed to resolve some aspect of marriage equality. Supported by the NPP, activist groupings and individuals from the major parties, civil society is revitalising referendums as a tool of democratisation.

The changes to Taiwan's Referendum Act have lowered barriers to popular political participation in an era of youth power. Following the Sunflower Movement, a young generation of activists working from both within parliament and through civil society organisations are reframing politics as the concern of every citizen and not just the stomping grounds of privileged families and established organisations. Where the KMT opposed same-sex marriage and the DPP faltered, the NPP championed the cause.

So what exactly is new about the New Power Party? In a sense, the spiritual successor of the DPP, it represents a new generation of Taiwanese activists. Although the same-sex marriage referendums were voted down and the DPP lost significant ground in the 2018 elections, the NPP nevertheless won 16 council seats. Part of the continuing processes of localisation and democratisation, the NPP articulates 'natural independence' 天然獨, advocating for a generation of Taiwanese young people who embrace local identity and want to realign politics with the grassroots. Working in tandem with a generational shift towards Taiwan-centrism as the new socio-cultural norm, new politics delegitimises the political hegemony of the two parties, the DPP and its 'pan-green' allies versus the KMT and its 'pan-blue' supporters. Advocates of this new politics assume the contest over national identity has already been decided, and that there is a need for new thinking in the political sphere. Whether the NPP can maintain its momentum and revolutionise Taiwan's political system yet remains to be seen. 
This text is taken from China Story Yearbook 2018: Power, edited by Jane Golley, Linda Jaivin, Paul J. Farrelly and Sharon Strange, published 2019 by ANU Press, The Australian National University, Canberra, Australia.

doi.org/10.22459/CSY.2019.06B 